\title{
INVERTED VERSUS DIRECT STRUCTURE BULK HETEROJUNCTION ORGANIC SOLAR CELLS INVOLVING A TRIPHENYLAMINE-BASED SMALL MOLECULAR DONOR
}

\author{
GAVRIL-IONEL GIURG| ${ }^{a, b}$, LORANT SZOLGA ${ }^{a, b, *}$, ISTVAN KOVACS ${ }^{c}$,

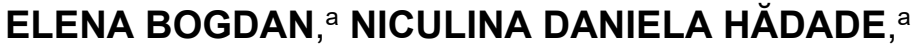 \\ ANAMARIA TEREC,${ }^{a}$ ION GROSU ${ }^{a, *}$, JEAN RONCALI ${ }^{a, *}$
}

\begin{abstract}
Bulk heterojunction solar cells involving a triphenylaminebased molecular donor and $\mathrm{PC}_{61} \mathrm{BM}$ with direct and inverted structures have been fabricated and optimized. The devices have been characterized under simulated solar illumination and the conversion efficiency and stability of the two kinds of organic solar cells are discussed.
\end{abstract}

Keywords: Organic solar cells, bulk heterojunction, inverted structure, molecular donors, triphenylamine derivatives

\section{INTRODUCTION}

In a general context marked by the foreseeable exhaustion of fossil energy resources and rising of environmental concerns, photovoltaic (PV) energy is expected to acquire a growing importance in the near future. While the PV industry is largely dominated by the silicon technology, recent years have witnessed an increasing research effort focused on the development of possible alternative technologies potentially more environmentally friendly and cost-effective such as, dye sensitized solar cells (DSSCs), perovskite solar cells and organic photovoltaic cells (OPV). [1, 2]

a Babes-Bolyai University, Faculty of Chemistry and Chemical Engineering, Department of Chemistry and SOOMCC, Cluj-Napoca, 11 Arany Janos str., 400028, Cluj-Napoca, Romania

b Optoelectronics Group, Base of Electronics Department, ETTI, Technical University of ClujNapoca, Str.Memorandumului, Nr.28, Cluj-Napoca, 400114, Romania

c IPA SA, Cercetare, Proiectare si Productie de Echipamente si Instalatii de Automatizare, Sucursala CIFATT Cluj, 15 Zorilor str., 400335, Cluj-Napoca, Cluj, Romania

*Corresponding authors: lorant.szolga@bel.utcluj.ro, igrosu@chem.ubbcluj.ro, jeanroncali@gmail.com 
OPV cells can be fabricated by different techniques such as vacuum deposited multi-layer planar heterojunctions and solution-processed bulk heterojunction solar cells (BHJ). [3-7] This latter kind of device which combines low-cost, simplicity and efficiency has progressively become the most widely developed and most successful technology of fabrication of OPV cells. BHJs were initially fabricated with a "direct" structure namely by spin-casting a solution of donor and acceptor materials on an indium-tin oxide (ITO) conducting electrode coated with a spin-cast layer of poly(3,4-ethylenedioxythiophene): polystyrene sulfonate (PEDOT:PSS) in order to smooth the surface and facilitate hole-extraction. However the acidity of PEDOT:PSS has been identified as one of the cause of instability of direct BHJ cells. An alternative technique consists in the realization of an inverted structure in which a solution-processed $\mathrm{ZnO}$ interlayer is inserted between the ITO electrode and the active layer thus removing the use of PEDOT:PSS. [8-11]

In this work we present a comparative analysis of the BHJ cells fabricated by the two techniques using a small molecular donor (D) consisting of a triphenylamine connected to a dicyanovinyl group by a thienyl ring (1) [12] and [6,6]-phenyl- $\mathrm{C}_{61}$-butyric acid methyl ester $\left(\mathrm{PC}_{61} \mathrm{BM}\right)$ as the acceptor $(\mathbf{A})$. Donor 1 was selected for its easy synthesis and relevant properties among the other small donors investigated in our group. [13-16] Various parameters involved in the fabrication of direct and inverted $\mathrm{BHJ}$ cells have been investigated including the donor/acceptor ratio, the thickness of the active layer and the conditions of its deposition by spin-coating (nature of the solvent and speed of rotation).

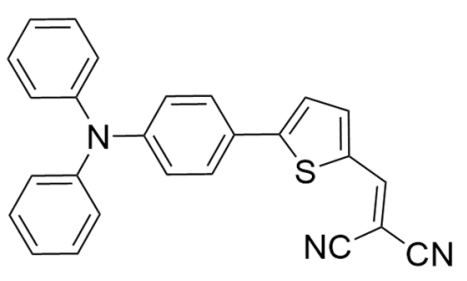

1

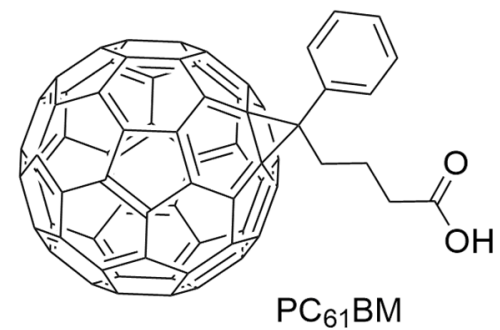

$\mathrm{PC}_{61} \mathrm{BM}$

Figure 1. Chemical structures for donor 1 and $\mathrm{PC}_{61} \mathrm{BM}$

\section{RESULTS AND DISCUSSIONS}

OPV cells based on donor 1 and fullerene $C_{60}$ fabricated by successive vacuum deposition of the donor and $\mathrm{C}_{60}$ have already been reported. A power conversion efficiency $(P C E)$ of $2.50 \%$ was reported for a bilayer cell while a 
hybrid cell fabricated by co-evaporation of the donor and $\mathrm{C}_{60}$ gave a PCE of 4.0\%. [17-19] However, the fabrication of solution-processed BHJ cells based on donor 1 has not been investigated in detail yet.

Figure 2 shows the structure of the direct and inverted devices investigated here. Except for the deposition of the metal electrodes, all experiments related to the fabrication and characterization of the cells were carried out in ambient conditions.

\section{$B H J$ with direct structure (ITO/PEDOT:PSS/1, PC $\left.{ }_{61} B M / A I\right)$.}

In a first step two solvent systems have been compared for the processing of the active layer namely chloroform (CF) / chlorobenzene (CB) (1/1) and chloroform (CF) / dichlorobenzene (DCB) (1/1). Although the donor $1 / \mathrm{PC}_{61} \mathrm{BM}$ blend is readily dissolved in both systems, the CF/CB mixture produced more uniform and more compact films on the PEDOT:PSS layer. The CF / DCB mixture lead to hollow spin-cast films unsuitable for OSC fabrication.

Using the 1/1 CF / CB solutions BHJs with active layers of 80,125 and $170 \mathrm{~nm}$ thickness were fabricated. The best results (PCE $=1.02 \%)$ were obtained with the thinnest film $(80 \mathrm{~nm})$, while PCE decreases to $0.66 \%$ when increasing film thickness to $170 \mathrm{~nm}$ (Table 1).
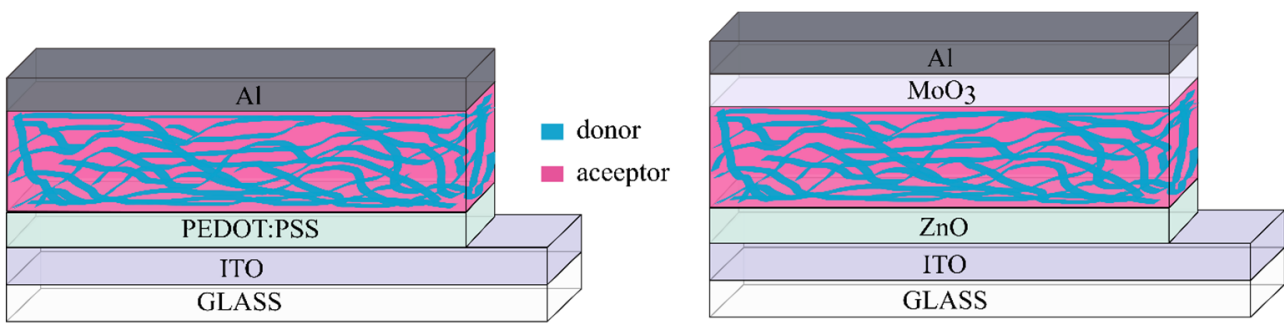

Figure 2. Simplified representations of direct (left) and inverted (right) $\mathrm{BHJ}$ organic solar cells

Table 1. Effect of the thickness of the active layer on the average values of the photovoltaic characteristics of direct BHJ cells with 1:1 1/PC ${ }_{61} \mathrm{BM}$ ratio

\begin{tabular}{|c|c|c|c|c|c|}
\hline $\begin{array}{c}\text { Spin-coating program and } \\
\text { rotation speed }\end{array}$ & $\begin{array}{c}\text { Thickness } \\
{[\mathrm{nm}]}\end{array}$ & $\begin{array}{c}V_{\mathrm{oc}} \\
{[\mathrm{V}]}\end{array}$ & $\begin{array}{c}J_{\mathrm{sc}} \\
{\left[\mathrm{mA} \mathrm{cm}^{-2}\right]}\end{array}$ & $\begin{array}{c}F F \\
{[\%]}\end{array}$ & $\begin{array}{c}P C E \\
{[\%]}\end{array}$ \\
\hline $1000 \mathrm{rpm} / 40 \mathrm{~s}+8000 \mathrm{rpm} / 20 \mathrm{~s}$ & 80 & 0.85 & 4.46 & 29 & 1.02 \\
\hline $700 \mathrm{rpm} / 60 \mathrm{~s}+3000 \mathrm{rpm} / 20 \mathrm{~s}$ & 125 & 0.85 & 3.60 & 27 & 0.85 \\
\hline $500 \mathrm{rpm} / 60 \mathrm{~s}+3000 \mathrm{rpm} / 20 \mathrm{~s}$ & 170 & 0.85 & 3.00 & 27 & 0.66 \\
\hline
\end{tabular}


Using the spin-casting conditions leading to $80 \mathrm{~nm}$ thick films, a series of cells with D/A ratios of $2: 1 ; 1: 1 ; 1: 2 ; 1: 3$ and $1: 4$ were fabricated and characterized. Figure 3 shows the UV-Vis absorption spectra of the films obtained with these various D/A ratios. The different D/A ratios are clearly illustrated by the variation of the relative intensities of the absorption band around $380 \mathrm{~nm}\left(\mathrm{PC}_{61} \mathrm{BM}\right)$ and $520 \mathrm{~nm}$ (1). Figure 4 shows the current density $v s$ voltage curves for the best cells obtained with various D/A ratios, while the corresponding data are listed in Table 2.

The best $P C E$ value $(1.50 \%)$ is obtained with a D/A ratio of $1: 3$, while $\mathrm{D} / \mathrm{A}=2: 1$ and $1: 1$ lead to lower values ( $P C E=0.66 \%$ and $1.02 \%)$. An opencircuit voltage $\left(V_{o c}\right)$ of $1.04 \mathrm{~V}$ is obtained with $\mathrm{D} / \mathrm{A}=2: 1$ and decreases to $0.86 \mathrm{~V}$ for $\mathrm{D} / \mathrm{A}=1: 4$. On the other hand, the short-circuit current density $\left(J_{\mathrm{sc}}\right)$ increases from $2.70 \mathrm{~mA} \mathrm{~cm}^{-2}$ for $D / A=2: 1$ to $4.94 \mathrm{~mA} \mathrm{~cm}^{-2}$ for $D / A=1: 3$, this $D / A$ ratio leading to the maximum $P C E$ of $1.54 \%$. All devices show relatively low fill factors $(F F)$ in the range of $30 \%$, such modest $F F$ values frequently observed with TPA-based push-pull donor have been attributed to their low hole mobility and to problems related to the extraction of charges at the active layer/electrode interfaces.

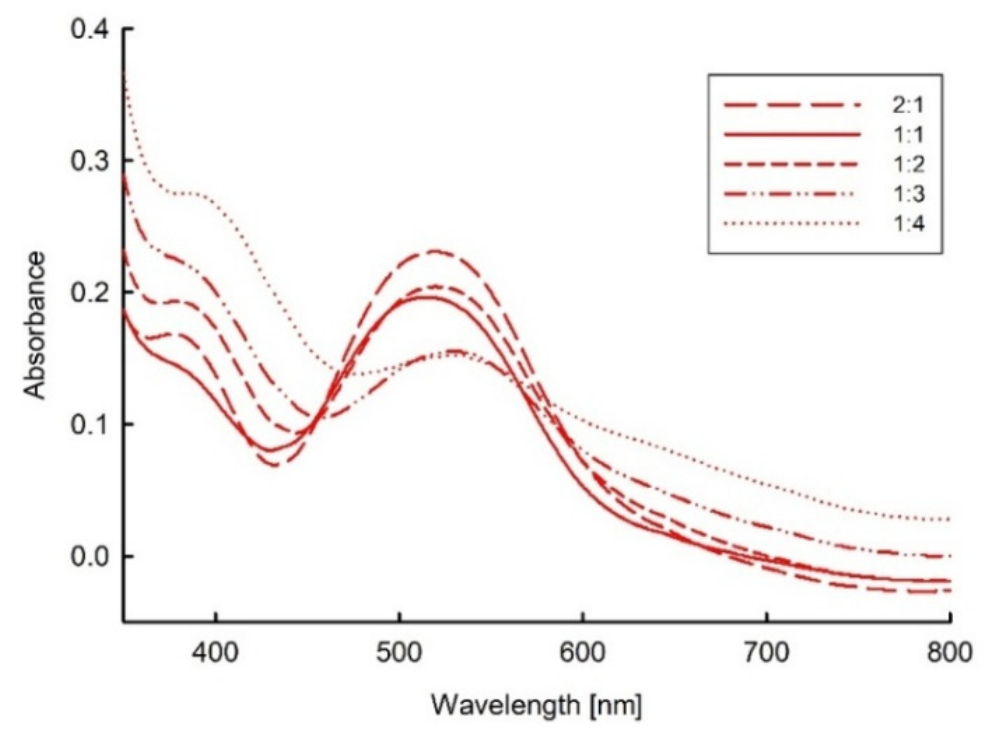

Figure 3. UV-VIS spectra of the films spun-cast with different D/A ratios 


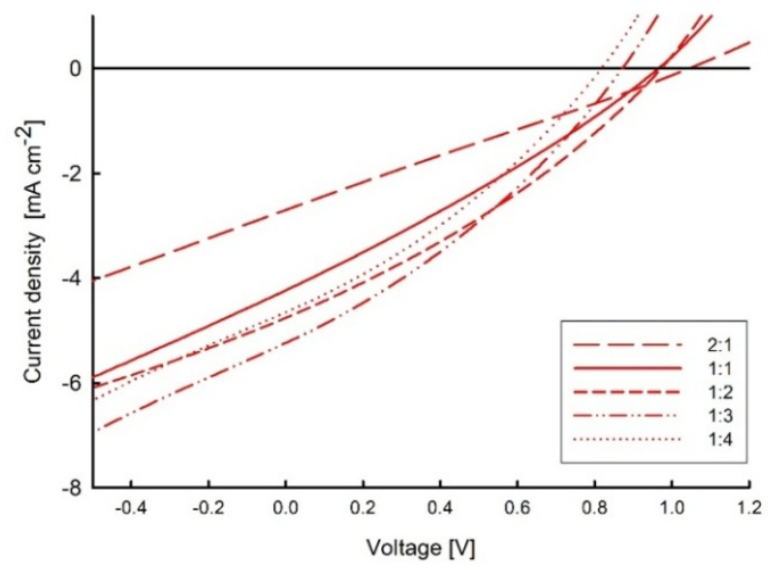

Figure 4. Current density vs voltage curves for direct $\mathrm{BHJ}$ cells fabricated with various D/A ratios, AM 1.5 simulated solar light with a power light intensity of $100 \mathrm{mWcm}^{-2}$.

The external quantum efficiencies of the cells under monochromatic irradiation $(E Q E)$ are shown in Figure 5.

These action spectra show a first band around $380 \mathrm{~nm}$ which increases with the $\mathrm{PC}_{61} \mathrm{BM}$ content and corresponds to its contribution to the photocurrent. The main band extending from 450 to $650 \mathrm{~nm}$ corresponds to the charge transfer band of the donor and shows a maximum intensity for $D / A=1: 3$, in good agreement with the results obtained under simulated solar light. It is noted that this ratio also corresponds to the maximum contribution of $\mathrm{PC}_{61} \mathrm{BM}$, suggesting that the morphology of the bi-phase D/A blend is optimum at this ratio.

Table 2. Optical and photovoltaic characteristics of direct BHJ cells fabricated with various $D / A$ ratios

\begin{tabular}{|c|c|c|c|c|c|}
\hline D/A Ratio & $\begin{array}{c}V_{\mathrm{oc}} \\
{[\mathrm{V}]}\end{array}$ & $\begin{array}{c}J_{\mathrm{sc}} \\
{\left[\mathrm{mA} \mathrm{cm}^{-2}\right]}\end{array}$ & $\begin{array}{c}F F \\
{[\%]}\end{array}$ & $\begin{array}{c}P C E \\
{[\%]}\end{array}$ & $\begin{array}{c}E Q E_{\max } \\
{[\%]}\end{array}$ \\
\hline $2: 1$ & 1.04 & 2.70 & 25 & 0.71 & 22 \\
\hline $1: 1$ & 0.96 & 4.23 & 28 & 1.16 & 25 \\
\hline $1: 2$ & 0.97 & 4.76 & 31 & 1.44 & 33 \\
\hline $1: 3$ & 0.93 & 4.94 & 33 & 1.54 & 34 \\
\hline $1: 4$ & 0.86 & 4.69 & 31 & 1.28 & 25 \\
\hline
\end{tabular}




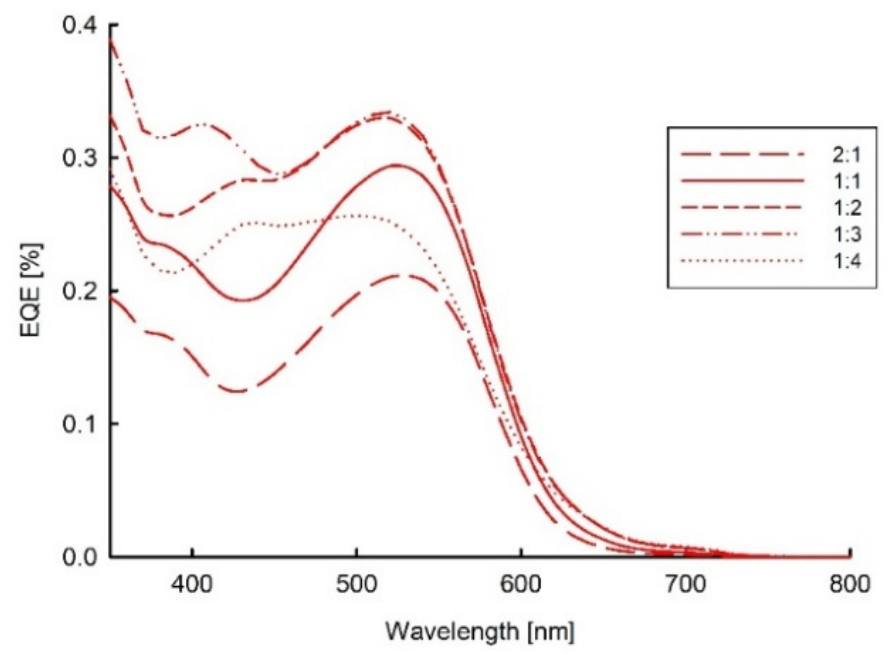

Figure 5. EQE responses for the best direct $\mathrm{BHJ}$ cells fabricated with the various $D / A$ ratios

\section{$\mathrm{BHJ}$ with inverted structure (ITO/ZnO/1, $\left.\mathrm{PC}_{61} \mathrm{BM} / \mathrm{MoO}_{3} / \mathrm{Al}\right)$}

As a next step, a series of inverted cells of structure (ITO/ZnO/1, $\mathrm{PC}_{61} \mathrm{BM} / \mathrm{MoO}_{3} / \mathrm{Al}$ ) with D/A ratios of $1: 1,1: 2$ and $1: 3$ and a thickness of the active layer of $80 \mathrm{~nm}$ have been fabricated. The $\mathrm{ZnO}$ layer improves the charge extraction from the blend D/A layer by enhancing electron transport to the ITO electrode while the $\mathrm{MoO}_{3}$ layer improves hole-transport and contributes to protect the active layer from oxygen and moisture that play a major role in the device degradation. For $\mathrm{ZnO}$ a layer thickness of 25-30 nm is optimum, while for $\mathrm{MoO}_{3}$ the optimal thickness depends on the nature of the metal electrode. Au presents the highest electrical conductivity, but Al and $\mathrm{Ag}$ have better optical transparency. [20] The inverted cells have been fabricated with $\mathrm{Ag}$ and $\mathrm{Al}$ electrodes with a constant thickness of the $\mathrm{MoO}_{3}$ layer. In a first set of experiments a $7 \mathrm{~nm}$ of $\mathrm{MoO}_{3}$ was used, but it results in short-circuited cells with both type of electrodes. Increasing the thickness of the $\mathrm{MoO}_{3}$ to $10 \mathrm{~nm}$, leads to working cells with Al electrodes but attempt to fabricate cells with silver electrodes remain unsuccessful, presumably because of the experimental set-up for silver vacuum deposition was not adapted.

The current density vs voltage curves of the inverted cells fabricated with various D/A ratios and a $10 \mathrm{~nm} \mathrm{MoO}$ layer are shown in Figure 6 and the corresponding photovoltaic parameters are listed in Table 3. The highest 
average $P C E$ of $1.83 \%$ was obtained with the $1: 3 \mathrm{D} / \mathrm{A}$ ratio while the highest $P C E$ value $(2.00 \%)$ was measured on a cell based on a 1:2 D/A ratio. As for direct cells, a small increase of $V_{\text {oc }}$ with the donor content is observed, but on the characteristics of the various cells are rather similar with in particular $J_{\mathrm{sc}}$ values of $5.40-5.70 \mathrm{~mA} \mathrm{~cm}{ }^{-2}$. The most noticeable difference with direct cells is a significant improvement of $F F$ from ca $25 \%$ for direct cells to $35 \%$ for the inverted ones, suggesting that the inverted structure leads to a better extraction of photo-generated charges.

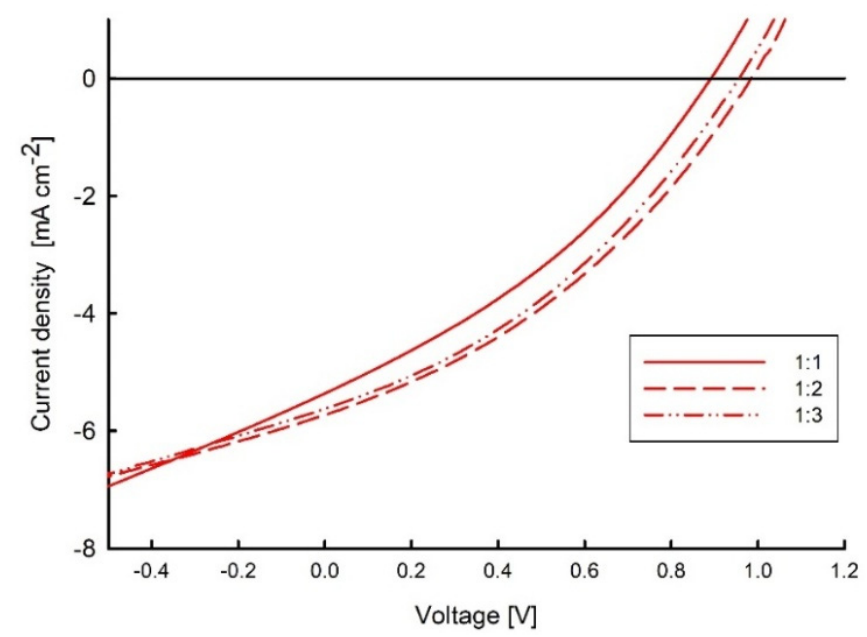

Figure 6. Current density vs voltage curves for best inverted $\mathrm{BHJ}$ cells fabricated with various D/A ratios, AM 1.5 simulated solar light with a power light intensity of $100 \mathrm{mWcm}^{-2}$.

The EQE spectra of the various cells recorded under monochromatic irradiation show a maxim of ca $35 \%$ around $520 \mathrm{~nm}$ (Figure 7). Except for an increase of the short wavelength band reflecting the increase of the acceptor content, the three spectra are very similar which agrees well with the results obtained under white light irradiation.

In order to investigate the long term stability of the two types of devices direct and inverted cells were stored in ambient conditions and the conversion efficiency was recorded at various time intervals (Figure 8). Figure 8 compares the variation of $P C E$ vs time for direct and inverted cells. The PCE of the direct cells drops down from 0.93 to $0.18 \%$ after 24 hours and to $0.08 \%$ after 10 days. 
GAVRIL-IONEL GIURGI, LORANT SZOLGA, ISTVAN KOVACS, ELENA BOGDAN, NICULINA DANIELA HĂDADE, ANAMARIA TEREC, ION GROSU, JEAN RONCALI

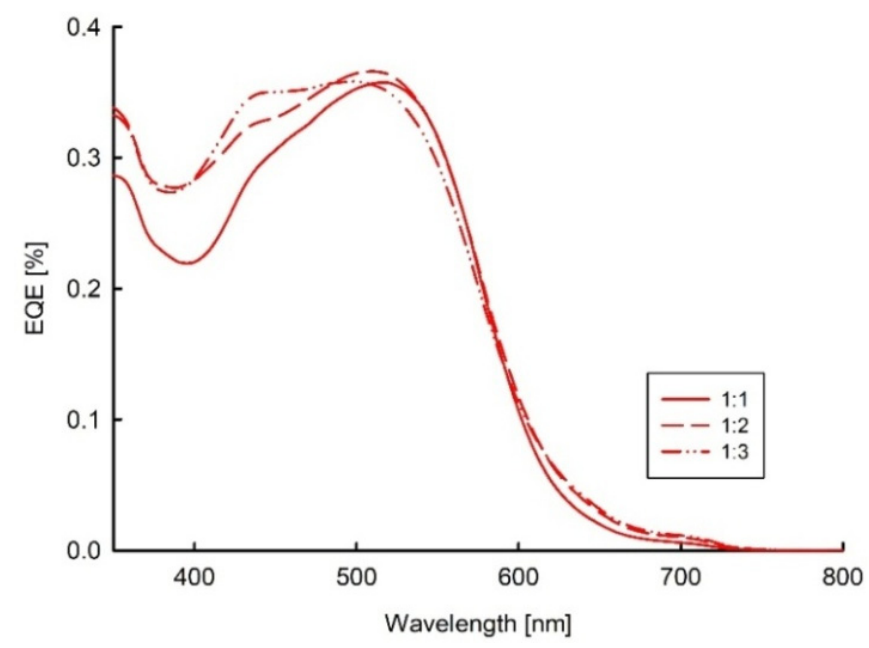

Figure 7. EQE spectra recorded under monochromatic illumination for the best inverted $\mathrm{BHJ}$ cells fabricated with various D/A ratios

Table 4. Photovoltaic characteristics under AM 1.5 simulated solar light for inverted $\mathrm{BHJ}$ cells fabricated with various D/A ratios.

\begin{tabular}{|c|c|c|c|c|c|}
\hline D/A Ratio & $\begin{array}{c}V_{\mathrm{oc}} \\
{[\mathrm{V}]}\end{array}$ & $\begin{array}{c}J_{\mathrm{sc}} \\
{\left[\mathrm{mA} \mathrm{cm}^{-2}\right]}\end{array}$ & $\begin{array}{c}F F \\
{[\%]}\end{array}$ & $\begin{array}{c}P C E \\
{[\%]}\end{array}$ & $\begin{array}{c}E Q E_{\max } \\
{[\%]}\end{array}$ \\
\hline $1: 1$ & 0.89 & 5.36 & 34 & 1.62 & 34 \\
\hline $1: 2$ & 0.98 & 5.72 & 35 & 2.00 & 36 \\
\hline $1: 3$ & 1.04 & 5.40 & 35 & 1.99 & 34 \\
\hline
\end{tabular}

For the inverted cells PCE shows a much slower decrease since the initial value of $1.50 \%$ decreases to $1.35 \%$ after 10 days and to $1.07 \%$ after 50 days. To summarize, the results clearly show that in the absence of encapsulation, the inverted structure leads to a considerable improvement of the stability of BHJ cells in ambient atmosphere. 
INVERTED VERSUS DIRECT STRUCTURE BULK HETEROJUNCTION ORGANIC SOLAR CELLS INVOLVING A TRIPHENYLAMINE-BASED SMALL MOLECULAR DONOR

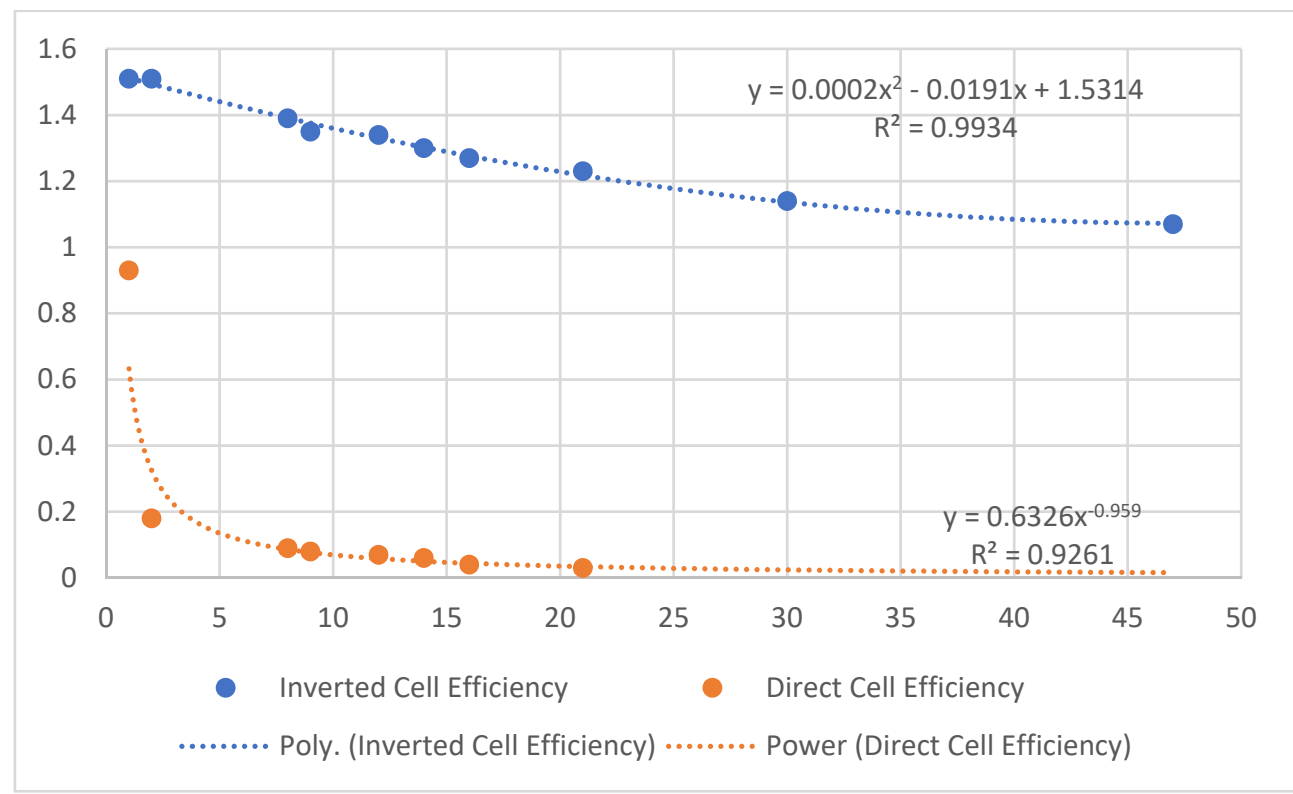

Figure 8. Variation of the PCE of direct and inverted BHJ cells over a period of 50 days storage in ambient conditions

\section{CONCLUSIONS}

A comparative analysis of the photovoltaic performances of BHJ cells of direct and inverted structures and based on a small molecular donor and $\mathrm{PC}_{61} \mathrm{BM}$ has been presented. The results obtained after optimization of the thickness of the active layer and donor vs acceptor ratio show the inverted cells present a higher efficiency that direct devices, due essentially to an improvement of the fill factor which probably reflect a more efficient collection of charges at the electrodes. Furthermore, the performances of inverted cells are much less dependent on the donor/acceptor ratio than direct structures and exhibit higher efficiencies and considerably better stabilities than $\mathrm{BHJ}$ cells with direct structure based on the same active components. 
GAVRIL-IONEL GIURGI, LORANT SZOLGA, ISTVAN KOVACS, ELENA BOGDAN, NICULINA DANIELA HĂDADE, ANAMARIA TEREC, ION GROSU, JEAN RONCALI

\section{EXPERIMENTAL PART}

\section{Materials and equipment}

The cells were obtained using commercially available ITO-coated glass substrates of $24 \times 25 \mathrm{~mm}$. These substrates were sonicated for 10 minutes in distilled water, cleaned with Deconex (10 min), ethanol (10 min), isopropanol (10 min) and finally using an UV Ozone Cleaner for 20 minutes. $\mathrm{PC}_{61} \mathrm{BM}, \mathrm{PEDOT}$, PSS, $\mathrm{MoO}_{3}, \mathrm{CHCl}_{3}, \mathrm{C}_{6} \mathrm{H}_{5} \mathrm{Cl}$ and $\mathrm{Al}$ were commercially available. The active material and $\mathrm{ZnO}$ were prepared accordingly to literature data. [21] The deposition of different layers of the cells were carried out either using a classic spin-coater or a high vacuum deposition equipment (MANTIS DEPOSITION- model QUBE). The characterization of the cells was performed with an Artificial Sun system LCS-100 (94011A-ES) and a monochromator equipment IQE 200B Quantum Efficiency Measurement Solution, while the thickness of the layers was measured using a profilometer Tencor Alpha-Step D500. The absorption spectra of the film were analyzed by UV-VIS 1900 Shimadzu spectrometer.

\section{General procedure for the fabrication of direct BHJs}

A PEDOT/PSS layer of $35-40 \mathrm{~nm}$ was spun-cast at $5000 \mathrm{rpm}$ for $30 \mathrm{~s}$ on clean ITO plates. The active layer was then deposited by spin-casting and the thickness was controlled by the spin-casting conditions (for $80 \mathrm{~nm}: \mathrm{t}_{1}=40$ $\mathrm{s}, \mathrm{S}_{1}=1000 \mathrm{rpm}, \mathrm{t}_{2}=20 \mathrm{~s}, \mathrm{~S}_{2}=8000 \mathrm{rpm}$; for $125 \mathrm{~nm}: \mathrm{t}_{1}=60 \mathrm{~s}, \mathrm{~S}_{1}=700 \mathrm{rpm}$, $\mathrm{t}_{2}=20 \mathrm{~s}, \mathrm{~S}_{2}=3000 \mathrm{rpm}$; for $170 \mathrm{~nm}: \mathrm{t}_{1}=60 \mathrm{~s}, \mathrm{~S}_{1}=500 \mathrm{rpm}, \mathrm{t}_{2}=20 \mathrm{~s}, \mathrm{~S}_{2}=3000$ $\mathrm{rpm})$. The $100 \mathrm{~nm}$ Al electrodes were deposited by thermal evaporation under high-vacuum deposition system at $1 \times 10^{-6} \mathrm{mbar}$.

\section{General procedure for the fabrication of inverted BHJs}

A layer of $40 \mathrm{~nm} \mathrm{ZnO}$ was deposited by spin-casting [S = $3000 \mathrm{rpm}$, $\mathrm{t}=40 \mathrm{~s}$ ) on clean ITO plates and then the plates were heated at $200{ }^{\circ} \mathrm{C}$ for 1h. The films of donor 1: $\mathbf{P C}_{61} \mathbf{B M}$ with a thickness of $80 \mathrm{~nm}$ were deposited by spun-cast ( $\left.\mathrm{t}_{1}=40 \mathrm{~s}, \mathrm{~S}_{1}=1000 \mathrm{rpm}, \mathrm{t}_{2}=20 \mathrm{~s}, \mathrm{~S}_{2}=8000 \mathrm{rpm}\right)$ on top of $\mathrm{ZnO}$ layer. The hole transporter layer $(\mathrm{HTL})$ consisting in a $10 \mathrm{~nm}$ thick $\mathrm{MoO}_{3}$ layer and the Al electrodes $(100 \mathrm{~nm})$ were deposited by thermal evaporation under high vacuum at $10^{-6}$ mbar. 
INVERTED VERSUS DIRECT STRUCTURE BULK HETEROJUNCTION ORGANIC SOLAR CELLS INVOLVING A TRIPHENYLAMINE-BASED SMALL MOLECULAR DONOR

\section{ACKNOWLEDGEMENTS}

This work was financial supported by the project SMOSCs, ID: 37 220, Cod MySMIS: 103509 funded by the Romanian Ministry for European Funds through the National Authority for Scientific Research and Innovation (ANCSI) and co-funded by the European Regional Development Fund / Competitiveness Operational Program 2014-2020 (POC) Priority Axis $1 /$ Action 1.1.4

\section{REFERENCES}

1. J.A. Luceño-Sánchez, A.M. Díez-Pascual, R P. Capilla, Int. J. Mol. Sci. 2019, 20, nr. 976.

2. M. Hiramoto, Y. Shinmura, Organic Solar Cells in Springer Handbook of Electronic and Photonic Materials, S. Kasap, P. Capper eds. Springer Handbooks. Springer, 2017, Chapter 54, p 1329-1338.

3. S. Chambon, L. Derue, M. Lahaye, B. Pavageau, L. Hirsch, G. Wantz, Materials 2012, 5, $2521-2536$.

4. J. Lee, Y.K. Jung, D.Y. Lee, J.W. Jang, S. Cho, S. Sone, J. Jeong, S.H. Park, Synth. Met., 2015, 199, 408-412.

5. Z. Wang, Z. Hong, T. Zhuang, G. Chen, H. Sasabe, D. Yokoyama, J. Kido, Appl. Phys. Lett., 2016,106, 053305.

6. S. Rafiquea, S.M. Abdullah, K. Sulaiman, M. Iwamoto, Renew. Sustain. Energy, 2018, 84, 43-53.

7. M.C. Scharber, N.S. Sariciftci, Progr. Polym. Sci., 2013, 38, 1929-1940.

8. M.S. White, D. S. Olson, Appl. Phys. Lett. 2006, 89,143517.

9. K. Wang, C. Liu, T. Meng, C. Yia, X. Gong, Chem. Soc. Rev., 2016, 45, 29372975.

10. B. Gholamkhass, N.M. Kiasari, P. Servati, Org. Electron., 2012, 13, 945-953.

11. Y. Wang, H. Cong, B. Yu, Z. Zhang, X. Zhan, Materials, 2017, 10, 1064.

12. A. Leliège, C.H. Le Régent, M. Allain, P. Blanchard, J. Roncali, Chem. Commun. 2012, 48, 8907-8909.

13. A. Diac, D. Demeter, S. Jungsuttiwong, I. Grosu, J. Roncali, Tetrahedron Lett. 2015, 56, $4607-4612$.

14. A. Diac, D. Demeter, M. Allain, I. Grosu, J. Roncali, Chem. Eur. J., 2015, 21, $1598-1608$.

15. D. Demeter, S. Mohamed, A. Diac, I. Grosu, J. Roncali, ChemSusChem 2014, 7, 1046-1050. 
GAVRIL-IONEL GIURGI, LORANT SZOLGA, ISTVAN KOVACS, ELENA BOGDAN, NICULINA DANIELA HĂDADE, ANAMARIA TEREC, ION GROSU, JEAN RONCALI

16. A.P. Diac, L. Szolga, C. Cabanetos, A. Bogdan, A. Terec, I. Grosu, J. Roncali, Dyes and Pigments, 2019, 171, nr. 107748.

17. J.W. Choi, C.H. Kim, J. Pison, A. Oyedele, D. Tondelier, A. Leliège, E. Kirchner, P. Blanchard, J. Roncali, B. Geffroy, RSC Advances, 2014, 4, 5236-5242.

18. S. Mohamed, D. Demeter, J.-A. Laffitte, P. Blanchard, J. Roncali, SciRep 2015, 5, nr. 9031.

19. Y. Jiang, C. Cabanetos, M. Allain, S. Jungsuttiwong, J. Roncali, Org. Electron., 2016, 37, 294-304.

20. H.R. Yeom, J. Heo, G.-H. Kim, S.-J. Ko, S. Song, Y. Jo, J.Y. Kim, B. Walker, J.Y. Kim, Phys. Chem. Chem. Phys., 2015, 17, 2152-2159.

21. Y.M. Sun, J.H. Seo, C.J. Takacs, J. Seifter, A.J. Heeger, Adv. Mater, 2011, 23, 1679-1683. 